\title{
Research
}

\section{Climate Factors Play a Limited Role for Past Adaptation Strategies in West Africa}

\author{
Ole Mertz $^{1}$, Cheikh Mbow $^{2}$, Jonas $_{\text {Antergaard Nielsen }}{ }^{3}$, Abdou Maiga $^{4}$, Drissa Diallo $^{5}$, \\ Anette Reenberg $^{1}$, Awa Diouf ${ }^{2}$, Bruno Barbier ${ }^{6}$, Ibrahim Bouzou Moussa $^{7}$, Malicki Zorom ${ }^{8}$, \\ Ibrahim Ouattara $^{9}$, and Daniel Dabi ${ }^{10}$
}

\begin{abstract}
The Sudano-Sahelian zone of West Africa has experienced recurrent droughts since the mid-1970s and today there is considerable concern for how this region will be able to adapt to future climate change. To develop well targeted adaptation strategies, the relative importance of climate factors as drivers of land use and livelihood change need to be better understood. Based on the perceptions of 1249 households in five countries across an annual rainfall gradient of $400-900 \mathrm{~mm}$, we provide an estimate of the relative weight of climate factors as drivers of changes in rural households during the past 20 years. Climate factors, mainly inadequate rainfall, are perceived by $30-50 \%$ of households to be a cause of decreasing rainfed crop production, whereas a wide range of other factors explains the remaining 50-70\%. Climate factors are much less important for decreasing livestock production and pasture areas. Increases in pasture are also observed and caused by improved tenure in the driest zone. Adaptation strategies to declining crop production include 'prayer' and migration in the 400-500 mm zone; reforestation, migration, and government support in the 500-700 $\mathrm{mm}$ zone; and soil improvement in the 700-900 $\mathrm{mm}$ zone. Declining livestock holdings are countered by improved fodder resources and veterinary services. It is concluded that although rainfed crop production is mainly constrained by climate factors, livestock and pasture are less climate sensitive in all rainfall zones. This needs to be reflected in national adaptation strategies in the region.
\end{abstract}

Key Words: adaptation; climate variability; livestock; rainfed crops; West Africa

\section{INTRODUCTION}

Climate change and variability and their impact on human populations in sub-Saharan Africa are a major global concern. Calls for large-scale international assistance to finance adaptation to climate change have been reinforced in recent years (Parry et al. 2009, Patt et al. 2010). The SudanoSahelian zone of West Africa is an area of particular interest because of the recurrent drought periods commencing in the early 1970s (Nicholson 1978, Rain 1999) and the efforts in this area to adapt to drought. Averaged over 30-year intervals, annual rainfall in this area fell by between 20 and $30 \%$ between the 1930s and the 1950s and the three decades following the 1960s, prompting Hulme (2001:20) to state that "the African Sahel therefore provides the most dramatic example worldwide of climatic variability that has been directly and quantitatively measured." It is repeatedly argued that this change in rainfall had major consequences for the populations of the Sudano-Sahelian zone, already under stress from difficult economic conditions (Roncoli et al. 2001), even if a recovery of annual rainfall, particularly in the eastern part of the West African Sahel, has been observed during the past decade (Lebel and Ali 2009).

The question remains, however, to what extent climate factors have influenced development in the

\footnotetext{
${ }^{1}$ Department of Geography and Geology, University of Copenhagen, ${ }^{2}$ Institut des Sciences de l'Environnement, Faculté des Sciences et Techniques, Ecole Supérieure Polytechnique, Université Cheikh Anta Diop de Dakar, ${ }^{3}$ Waterworlds Research Centre, Department of Anthropology, University of Copenhagen, ${ }^{4}$ Département IRO, University de Montréal, ${ }^{5}$ Université de Bamako, Campus de Badalabougou, ${ }^{6}$ International Cooperation Center for Agronomic Research and Development (CIRAD), 'Département de Géographie, Université Abdou Moumouni, ${ }^{8}$ Institut International d'Ingénierie de l'Eau et de l'Environnement (2iE), ${ }^{9}$ Département de Géographie, Université de Ouagadougou, ${ }^{10}$ Department of Geography and Planning, Faculty of Environmental Sciences, University of Jos
} 
region. Although there is an increasing realization of the interplay of different driving forces for rural development and environmental change in the tropics (Lambin et al. 2001, Reynolds et al. 2007, Turner et al. 2007, Mbow et al. 2008), understanding the relative impact of climate factors is not straight forward (Reenberg 2001, Mortimore et al. 2005, Reid and Vogel 2006, Ziervogel et al. 2006, Reynolds et al. 2007, Thomas et al. 2007, Tschakert 2007, Barbier et al. 2009, Mertz et al. 2009b). This debate has gained increasing importance as it is realized that the impacts of climate change, all other things equal, will require significant adaptation in many different sectors of society (Adger et al. 2007, Mertz et al. 2009a). In developing countries, many of the impacts are likely to be more severe than elsewhere, and because of the low adaptive capacity especially in the least developed countries, the costs and scale of the needed adaptation strategies may be prohibitive for many people, communities, and nations (Adger et al. 2006, Mertz et al. 2009a). For that reason it is essential that adaptation strategies are either very specific and well targeted toward a very pressing need or designed in such a way that they become 'no regret' actions, which solve more general development problems while at the same time addressing impacts of climate change. Because of the triple exposure to accelerating population pressure, adverse economic conditions, and climatic variability (Leichenko and O'Brien 2008, Reenberg 2009), the development of narrow solutions to climate induced problems are likely to be ineffective or even counterproductive unless links to and feedbacks from other drivers of change are included. Therefore, to develop appropriate adaptation strategies, it is essential to obtain a better understanding of how important climate factors are in determining change.

The issue has been frequently debated using qualitative information (Mortimore and Adams 2001, Nielsen and Reenberg 2010a,b) and relatively small samples or localized field sites (Tschakert 2007, Mbow et al. 2008, West et al. 2008, Barbier et al. 2009, Mertz et al. 2009b). The general conclusions have often been that it is too complex and difficult to isolate the climate factor from other driving forces of change because decisions taken are often influenced by many nonclimatic conditions, some of which often appear to be more important than the climate factors (Eakin 2005, Ziervogel et al. 2006, Reid and Vogel 2006, Tschakert 2007, Mbow et al. 2008). Understanding the direct impact of climate factors on specific human populations thus requires the unraveling of a complex intertwinement of physical, biological, and socio-cultural systems (Oliver-Smith and Hoffman 2002). It is an exercise with which many studies on vulnerability, resilience, and adaptation to climate change struggle (Reid and Vogel 2006, Thomas et al. 2007, Leichenko and O'Brien 2008, Adger et al. 2009, Mertz et al. 2009b) and that is central to sustainability science (Turner et al. 2003, Turner et al. 2007).

In this paper, we provide an estimate of the relative weight of climate factors as a driver of change in rural households in the Sudano-Sahelian zone of West Africa during the past 20 years. We analyze perceptions of change in household income, crop production, livestock, and pasture as well as the causes of these changes.

\section{STUDY SITES AND METHODS}

This study took place in 15 sites in West Africa covering five countries, Senegal, Mali, Burkina Faso, Niger, and Nigeria, and three agroecological zones ranging from 400 to $900 \mathrm{~mm}$ of annual precipitation (Fig. 1). The rainy season is generally from June to September, longest in the wettest sites and shortest in driest areas. Based on an analysis of local rainfall data, average total rainfall has increased slightly in all sites since the droughts of the 1980s, but August rains have decreased in most sites. The rainfall patterns determine the choice of rainfed crops, which are mainly pearl millet (Pennisetum typhoides), sorghum (Sorghum bicolor), and cowpea (Vigna unguiculata) in the driest sites and also include maize (Zea mays) and peanuts (Arachis hypogaea) in the intermediate and wetter sites. Livestock is more important in the driest areas, but is found throughout all sites.

The field sites and sampling overview are presented in Table 1. A total of 1249 household questionnaires were administered as well as focus group discussions with separate groups of men and women in each community. The selection of households was, to the extent possible, completely randomized, but in the field certain households were unavailable and other households had to be included according to local leaders. For each site, the households from several villages or hamlets are merged in the analysis, mainly because intra-village differences between hamlets are often greater than intervillage differences. 
Fig. 1. Location of field sites in West Africa with isohyets. Source of isohyets: NASA gridded rainfall data in the GLOBAL GIS database (GlobalGISdatadatabasemapbasec_atmos). Acquired in 2005.

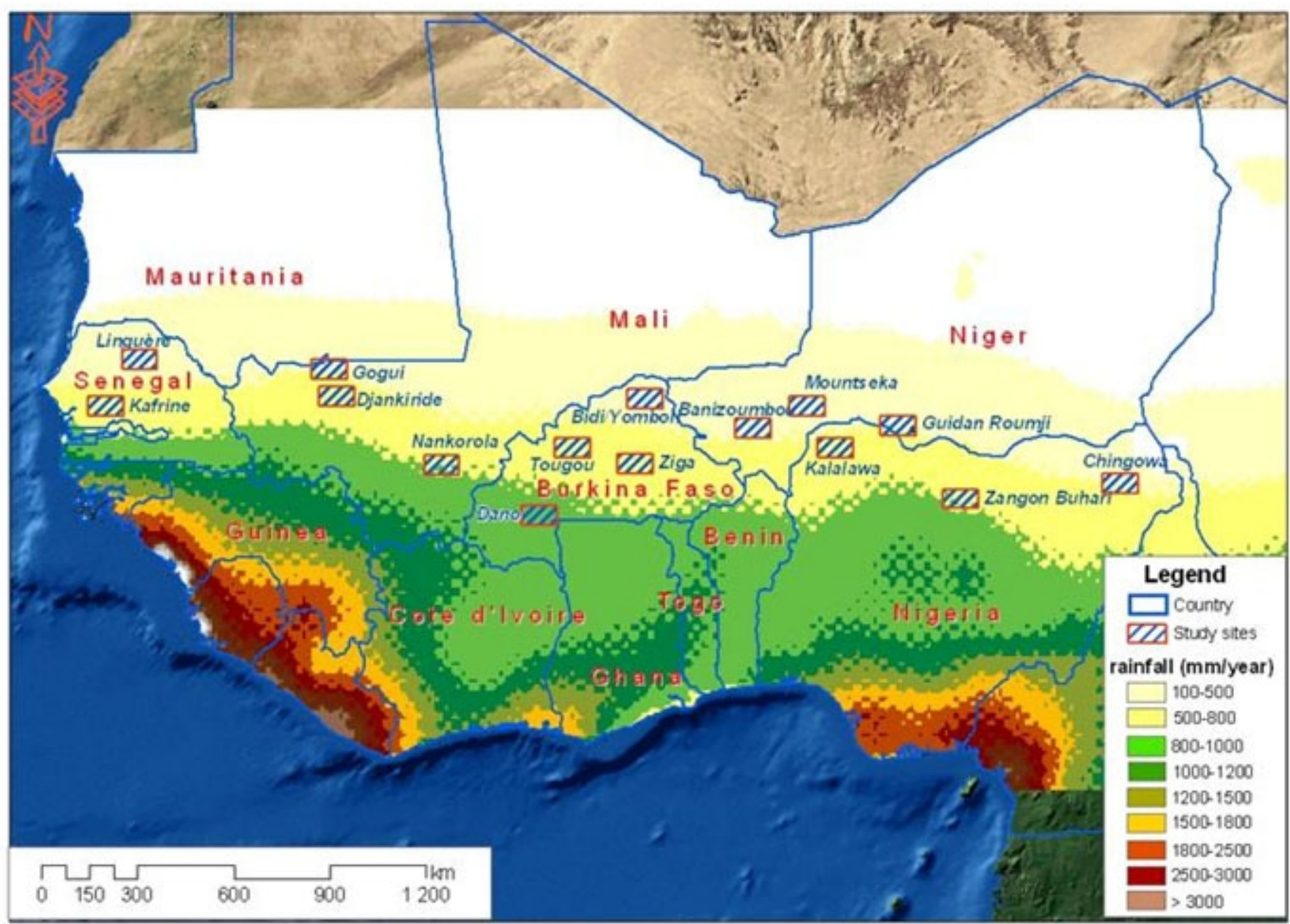

The household questionnaire was developed jointly by all authors and was implemented either by the authors or by trained research assistants in each community during the period of November 2007 to June 2008. The questionnaire was structured in such a way that for each category of questions, the respondents were asked to assess the current situation., e.g. main income source, number of animals, field size, etc., then to describe the main changes, if any, over the past 20 years (1987-2007), and finally to assess the main causes of these changes, if any. No indication of the focus on climate factors was presented for respondents at this stage to avoid biases in the answers. Toward the end of the questionnaire and to triangulate with responses in the first part of the questionnaire, the respondents were asked to directly assess positive and negative climate impacts on crop production and livestock production and, if negative, their adaptive actions to respond to these impacts. This was done as a free listing and responses were not ranked because there was rarely more than one to two adaptation measures mentioned. For all data, differences between rainfall zones were tested for significance using chi-square tests.

Most responses in the questionnaire are based on households' perceptions, which are used as a bestbet proxy for understanding causal relationships for changes. Perceptions are of course subjective and can be influenced by local or broader narratives and may also reflect the mind-set of individual farmers, 
Table 1. Field sites in West Africa with location, annual precipitation, and number of households (HH) sampled.

\begin{tabular}{|c|c|c|c|c|}
\hline Country & Site & $\begin{array}{l}\text { Location, UTM } \\
\text { coordinates }\end{array}$ & $\begin{array}{l}\text { Avg. annual } \\
\text { precip., mm }\end{array}$ & HH sampled \\
\hline \multirow[t]{5}{*}{ Burkina Faso } & Bidi- $2 \dagger$ & $\begin{array}{l}30 \mathrm{P}, 786000 \mathrm{E}, \\
1590000 \mathrm{~N}\end{array}$ & 450 & 41 \\
\hline & Yomboli $\dagger$ & $\begin{array}{l}30 \mathrm{P}, 786000 \mathrm{E}, \\
1621000 \mathrm{~N}\end{array}$ & 400 & 40 \\
\hline & Dano $\S$ & $\begin{array}{l}30 \mathrm{P}, 494000 \mathrm{E}, \\
1231000 \mathrm{~N}\end{array}$ & 900 & 105 \\
\hline & Tougou $\ddagger$ & $\begin{array}{l}30 \mathrm{P}, 581000 \mathrm{E}, \\
1513000 \mathrm{~N}\end{array}$ & 650 & 98 \\
\hline & Ziga $\S$ & $\begin{array}{l}30 \mathrm{P}, 736000 \mathrm{E}, \\
1396000 \mathrm{~N}\end{array}$ & 750 & 99 \\
\hline \multirow[t]{3}{*}{ Mali } & Dianguirdé $\ddagger$ & $\begin{array}{l}29 \mathrm{P}, 500000 \mathrm{E}, \\
1603000 \mathrm{~N}\end{array}$ & 600 & 106 \\
\hline & Gogui $\neq$ & $\begin{array}{l}29 \mathrm{P}, 465000 \mathrm{E}, \\
1734000 \mathrm{~N}\end{array}$ & 600 & 99 \\
\hline & Nankorola $\S$ & $\begin{array}{l}29 \mathrm{P}, 856000 \mathrm{E} \\
1401000 \mathrm{~N}\end{array}$ & 800 & 100 \\
\hline \multirow[t]{3}{*}{ Niger } & Banizoumbou $\dagger$ & $\begin{array}{l}31 \mathrm{P}, 493000 \mathrm{E}, \\
1529000 \mathrm{~N}\end{array}$ & 450 & 86 \\
\hline & Guidan Roumji $\dagger$ & $\begin{array}{l}32 \mathrm{P}, 251000 \mathrm{E}, \\
1511000 \mathrm{~N}\end{array}$ & 450 & 71 \\
\hline & Mountseka $\dagger$ & $\begin{array}{l}31 \mathrm{P}, 610000 \mathrm{E}, \\
1522000 \mathrm{~N}\end{array}$ & 450 & 93 \\
\hline \multirow[t]{3}{*}{ Nigeria } & Chingowa $\dagger$ & $\begin{array}{l}33 \mathrm{P}, 267000 \mathrm{E}, \\
1334000 \mathrm{~N}\end{array}$ & 500 & 45 \\
\hline & Kalalawa $\S$ & $\begin{array}{l}31 \mathrm{P}, 719000 \mathrm{E}, \\
1460000 \mathrm{~N}\end{array}$ & 750 & 50 \\
\hline & Zangon Buhari $\S$ & $\begin{array}{l}32 \mathrm{P}, 452000 \mathrm{E}, \\
1289000 \mathrm{~N}\end{array}$ & 800 & 47 \\
\hline \multirow[t]{2}{*}{ Senegal } & Barkedji $\dagger$ & $\begin{array}{l}28 \mathrm{P}, 514000 \mathrm{E}, \\
1688000 \mathrm{~N}\end{array}$ & 400 & 45 \\
\hline & Kaffrine $\ddagger$ & $\begin{array}{l}28 \mathrm{P}, 457000 \mathrm{E}, \\
1570000 \mathrm{~N}\end{array}$ & 630 & 124 \\
\hline TOTAL & & & & 1249 \\
\hline
\end{tabular}

$†$ 400-500 mm rainfall zone, total households sampled: 383

$\$ 500-700 \mathrm{~mm}$ rainfall zone, total households sampled: 472

$\S$ 700-900 mm rainfall zone, total households sampled: 404 
because some may be more prone to mention concrete causes that can be remedied, e.g. soil fertility, whereas others are more fatalistic, attributing causal factors beyond their control, e.g., weather. However, it can be reasonably assumed that households act on their perception of reality (Vedwan 2006, Slegers 2008) and for the complex analysis of what drives change and adaptive responses in rural Africa, there appears to be few other methods available. Moreover, research on traditional ecological knowledge shows that local people in general have a very good understanding of their biophysical surroundings and the changes to them, as well as the impacts of change over time and space (Inglis 1993, Berkes 1999).

\section{RESULTS}

The household income sources across the SudanoSahelian region are dominated by rainfed crop production and livestock, which are mentioned by more than $80 \%$ and $45 \%$ of respondents, respectively (Fig. 2a). Income from rainfed crops and livestock are most frequently mentioned in the wettest rainfall zone. The migration-based income is most important in the driest and intermediate zones. Although rainfed crops and livestock remain the two most important income sources, a majority of respondents claim that both have decreased over the past 20 years (Fig. 2b). A decline in income from crop production is mentioned by more than $70 \%$ of respondents and almost 50\% mention decreased livestock income. An increase in remittance income from migrants, vegetable farming, and various craftsman activities, e.g. carpenter, butcher, hairdresser, is mentioned by more than $40 \%$ of respondents.

Farmers' perceptions of change in the production of major rainfed crops, livestock, and the change in pasture areas are presented in Figure 3. There is an almost unanimous agreement across rainfall zones that all types of crop production per household have declined during the past 20 years. According to the perceptions of households, there has been an overall decrease in livestock numbers (Fig. 3). The number of cattle has decreased in all three rainfall zones but most significantly in the drier areas where more than $60 \%$ of households mention this decrease. In the $700-900 \mathrm{~mm}$ zone one third of the households have increased their cattle numbers, though this is surpassed by almost $50 \%$ that report a decrease. The situation is similar for goats (not shown in Fig. 3), whereas for sheep, the sharpest decrease is seen in the $500-700 \mathrm{~mm}$ zone, though almost $40 \%$ of households in the 700-900 $\mathrm{mm}$ zone report an increase.

Another key element for crop production and livestock in the region is the availability of good quality pastures. Even for settled farmers, most livestock is dependent on movement between pastures and animals are often commissioned to herders to ensure adequate nutrition. The household perceptions of change in permanent pastures and livestock corridors are also shown in Figure 3. There are very clear differences between the rainfall zones. In the dry zone, there is a relatively positive view because in all cases more than $50 \%$ of the households stated that the areas or corridors have remained stable or have increased during the past 20 years. Responses in the $500-700 \mathrm{~mm}$ rainfall zone are almost equally divided between positive and negative views of the changes, whereas in the wettest zone there is a very negative view of the development.

The respondents' perceptions of why income, crop and livestock production, and pasture have changed are shown in Fig. 4, where the relationship between climate and nonclimate factors attributed as causes of change are shown. Only causes of the most important trends are shown. The decrease in income from rainfed crop production is attributed to climate factors, mainly inadequate rainfall, in about $50 \%$ of the responses. The nonclimatic causes occur each with lower frequency, decreased soil fertility, pests, and reduced use of fertilizer being the most important. The income data are corroborated by the crop production data as inadequate rainfall again was the single most frequently mentioned production constraint for pearl millet, sorghum, and maize; pearl millet and sorghum show almost identical outcomes (only the former is shown in Fig. 4). On average $40 \%$ of households considered climate factors to have caused a decreased production of pearl millet, $30 \%$ in the wettest zone and $50 \%$ in the intermediate zone. Some maize growers in the driest zone also mentioned too much rain and flooding. Among the nonclimatic factors, soil fertility decline is also frequently mentioned as a cause and in the 700-900 mm zone it is ranked as high as inadequate rainfall. The last major cause observed is pest infestation, especially by larger animals, i.e., mammals and birds, which is considered a large problem for pearl millet by $30 \%$ of households in the intermediate zone. Poverty is 
Fig. 2. Household income sources in the Sudan-Sahel zone of West Africa. a) Percent of households mentioning the six most important income sources $(\mathrm{N}=2477, \mathrm{p}<0.05)$. b) Percent of households expressing changes in the six main household income categories during the past 20 years.

A
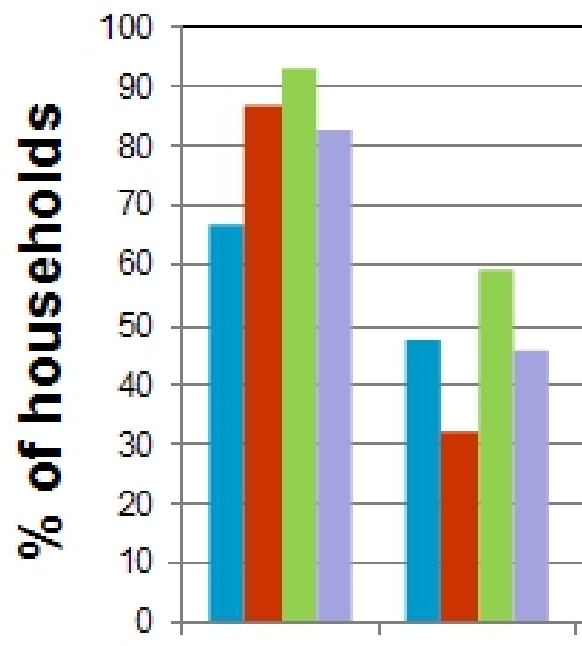

Rainfed crop

Livestock

Business

\section{Income source}

B

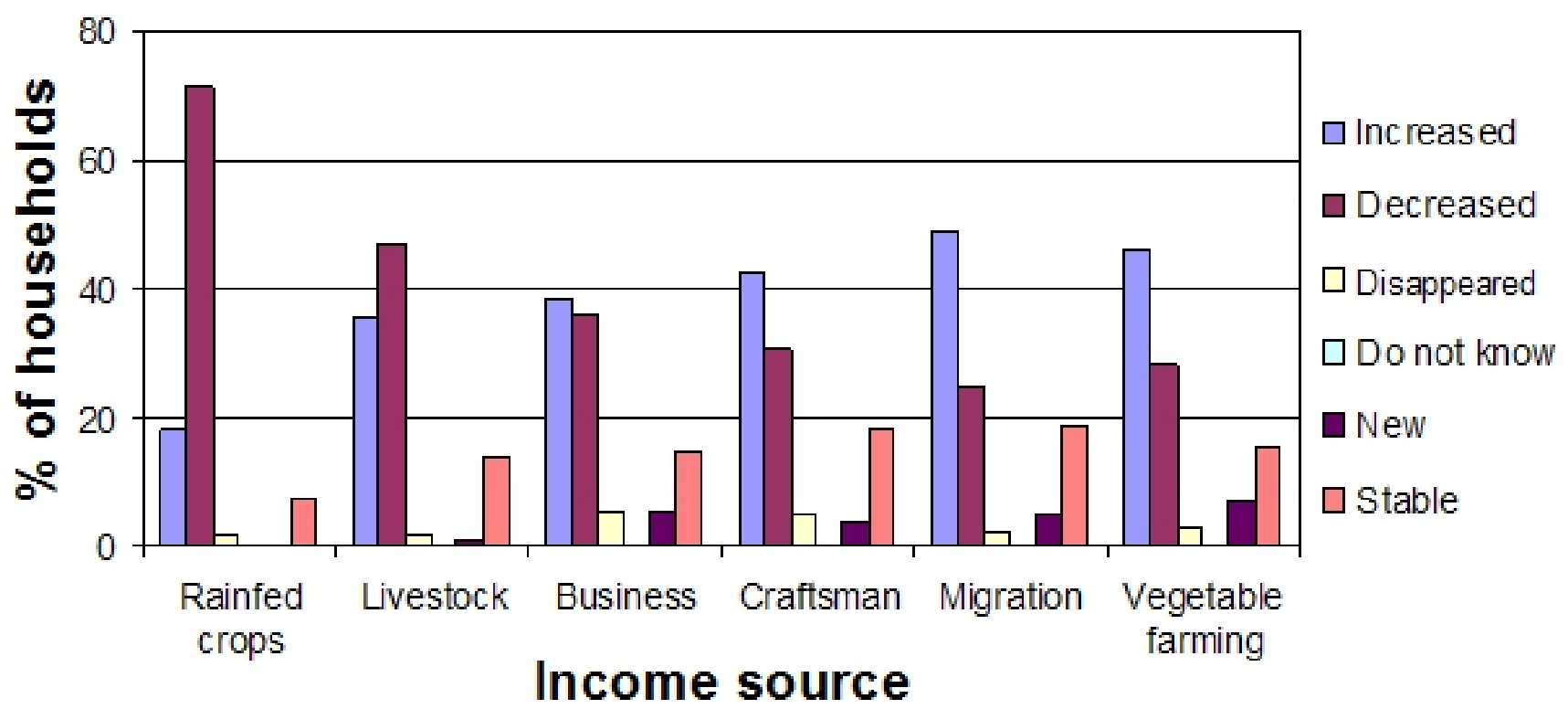

zones, $\mathrm{mm}$

400-500

500-700

700-900

Total farming

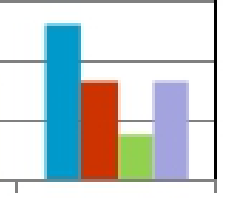

Craftsman 
Fig. 3. Percent of households in three rainfall zones stating a change or no change during the past 20 years in crop production (pearl millet, $\mathrm{N}=1056$, $\mathrm{p}<0.05$; sorghum, $\mathrm{N}=770, \mathrm{p}<0.05$; maize, $\mathrm{N}=468, \mathrm{p}<$ 0.05 ; and groundnuts, $\mathrm{N}=553, \mathrm{p}<0.05$ ), livestock production (cattle, $\mathrm{N}=575, \mathrm{p}<0.05$ and sheep, $\mathrm{N}=601, \mathrm{p}<0.05)$ and change in availability of permanent pasture $(\mathrm{N}=860, \mathrm{p}<0.05)$, and livestock corridors $(\mathrm{N}=852, \mathrm{p}<0.05)$. Significance levels refer to differences in perceptions between rainfall zones.
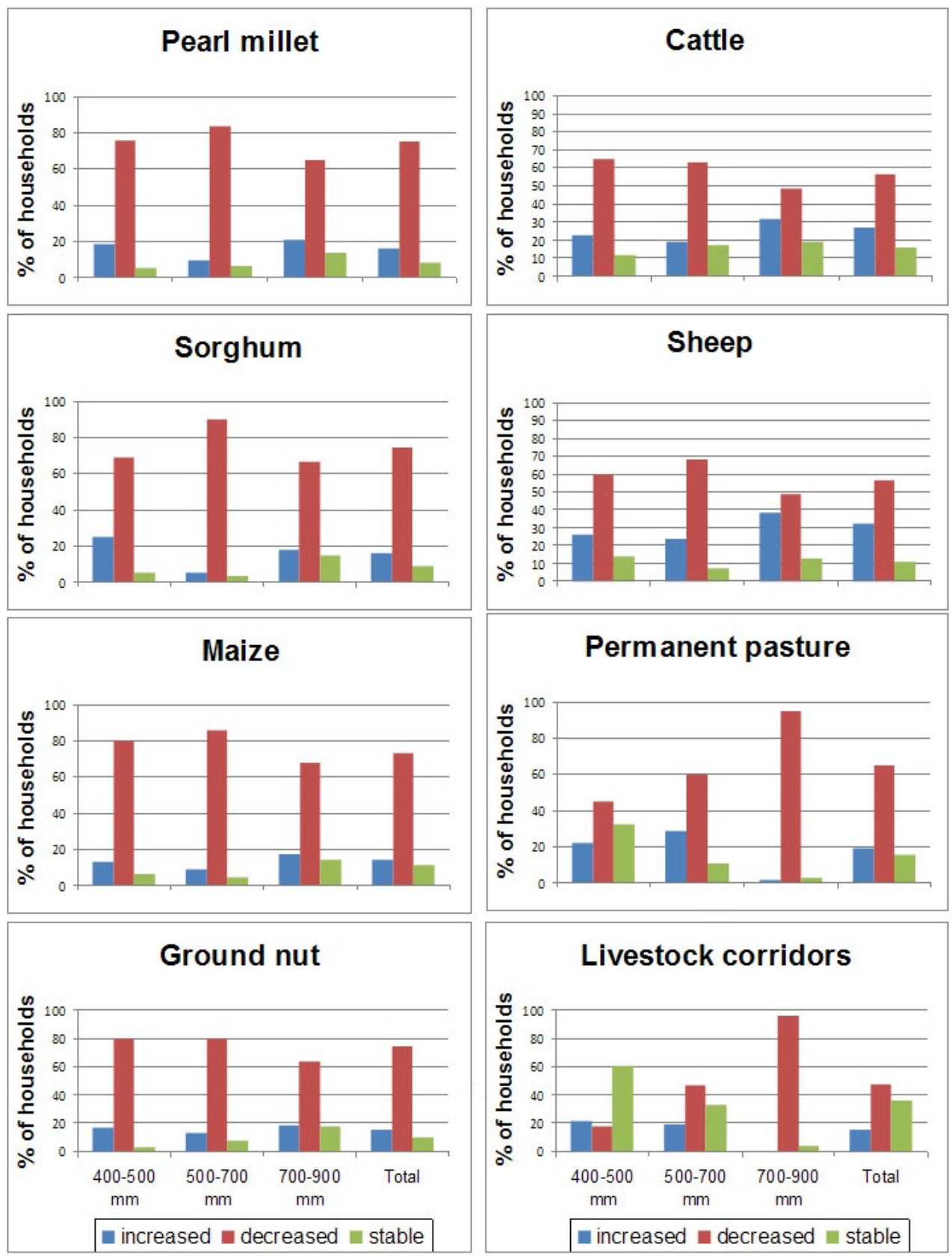
also mentioned by many farmers in the dry zone, and $8 \%$ mention lack of project support as a cause for the reduction of maize production.

The single most frequently mentioned cause of decreasing income from livestock is also inadequate rainfall. However, a wide range of nonclimatic causes including reduced pasture, livestock diseases, and sale of livestock because of family needs represent more than $70 \%$ of responses (Fig. 4). The main causes mentioned for a decrease in cattle, sheep, and goat numbers are not directly related to climatic factors and are highly dependent on the rainfall zone; in the dry zone the sale of livestock mostly because of increased family needs is by far the most important cause of cattle and goat decreases (goats not shown in Fig. 3). In the driest zone, the reduction in sheep is not caused by selloff to the same extent, but mainly attributed to rainfall decrease. Livestock diseases in cattle and goats are very frequent problems in the two wetter zones, whereas sheep are not as affected by disease. In the wettest zone, inadequate pasture, in terms of quality and quantity, and animal theft are also main problems leading to reductions in numbers. Overall, nonclimatic causes largely outweigh climatic causes of change.

The perceived causes of a reduction in the livestock pastures, corridors, and resting places are very clear. Agricultural expansion is mentioned in more than $60 \%$ of the total responses in all three categories (Fig. 4). Only in the driest zone does this figure drop below 50\% for the resting areas, but otherwise there is general agreement across the rainfall zones. This of course must be seen against the much higher proportion of respondents in the humid zone suggesting negative trends in all three categories. Population increase is overall the second most frequently mentioned cause and this can in many ways be considered a proxy for agricultural expansion, thus reinforcing this driver of perceived decreases in the pastoral areas. Climate factors are weakly represented in the responses, especially for resting areas and corridors. In the driest zone, about $14 \%$ of respondents who mentioned a decline in permanent pasture found insufficient rainfall to be its cause, but because only $40 \%$ of respondents found pasture to be declining, this represents a small number of responses in the sample. Flooding is mentioned by few households to occur in corridors and resting areas. Many households in the dry and intermediate zones stated that permanent pasture had increased or remained stable (Fig. 3). Very few provided causes for the stability, but increasing pastoral areas were frequently attributed to four similar causes: 1) rainfed crop cultivation has been reduced, 2) pastoral areas have been marked, 3) pastoral areas have been developed by the state and 4) land tenure issues have been resolved.

Finally, more than $70 \%$ of the households interviewed indicated that they have actively implemented some adaptation measure within rainfed crop production and livestock production in response to the negative trends in production (Fig. 5). Marked differences between the rainfall zones and a large diversity of answers, especially for crop production, are apparent. In the driest zone, there is a resigned attitude toward crop production as most households resort to prayer, increased food purchases, and migration. In the intermediate zone, many households also focus on migration, livelihood diversification, and government support, but the largest group see reforestation as the main adaptation strategy. In the wettest zone, the focus is much more on soil improvement as fertilization and soil and water conservation come out as the most cited strategies. For livestock, the overall diversity of answers is lower, although it is still high in the driest zone, where improved fodder, increased transhumance, and sale of livestock are the main responses. In the intermediate zone, almost half of the households pointed to the need for better veterinary services and in the wettest zone focus was on the fodder improvements, including further use of agricultural residues.

\section{DISCUSSION}

It is difficult to determine whether the perceived decline in rainfed crop production is correct in absolute terms. A main caveat to be observed relates to the propensity of farmers to say that yields were always better in the past and that farmers may not distinguish between yield (harvest per area unit) and total harvest. Thus, our question on total harvest may in some cases have been interpreted as pertaining to yield. However, the decline is highly likely to be correct in relative terms. Farmers may have related the production decline to the combination of increasingly large family size and migration of the labor force. Both of these factors may have caused the self-sufficiency in crop production to decline as fewer able-bodied people have to farm for a larger household composed of 
Fig. 4. The causes of change due to aggregated climate factors (rainfall, wind, temperature, drought, flooding, etc.) and aggregated nonclimate factors: decreasing income from crops $(\mathrm{N}=1044, \mathrm{p}=0.37$, nonsignificant) and livestock $(\mathrm{N}=311, \mathrm{p}<0.05)$, decreasing crop production (pearl millet, $\mathrm{N}=2501, \mathrm{p}<$ 0.05 ; maize, $\mathrm{N}=917, \mathrm{p}<0.05$ ) and livestock production (cattle, $\mathrm{N}=515, \mathrm{p}<0.05$; sheep, $\mathrm{N}=571, \mathrm{p}<$ 0.05 ), and change in pasture areas: permanent pasture (increasing $\mathrm{N}=134, \mathrm{p}<0.05$; decreasing $\mathrm{N}=560, \mathrm{p}$ $<0,05$ ), livestock corridors (increasing $\mathrm{N}=108, \mathrm{p}<0,05$; decreasing $\mathrm{N}=438, \mathrm{p}=0.21$, nonsignificant), and livestock resting areas (increasing $\mathrm{N}=111, \mathrm{p}<0.05$; decreasing $\mathrm{N}=392, \mathrm{p}=0.93$, nonsignificant). Significance levels refer to differences in perceptions between rainfall zones.
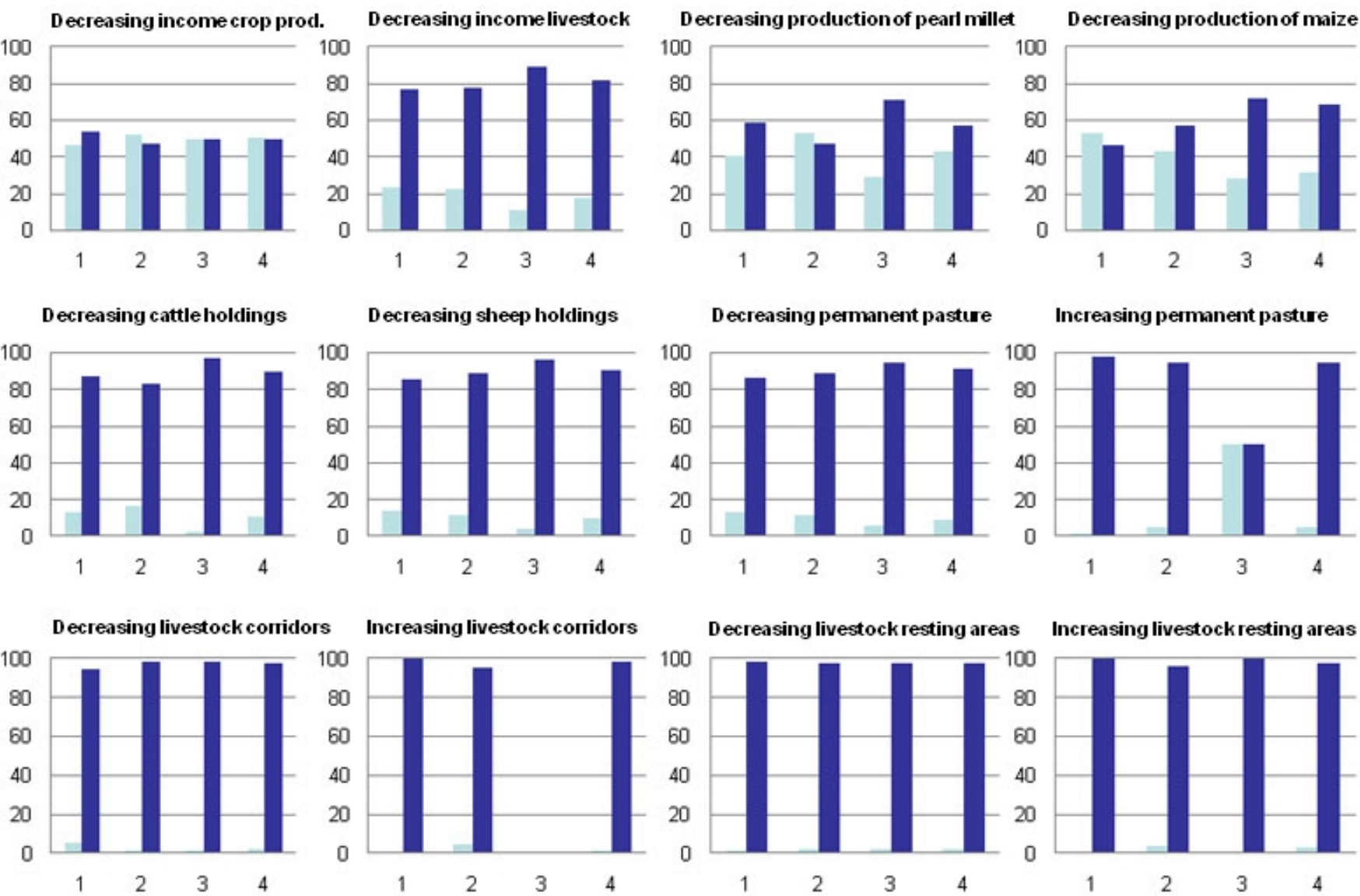

climate factors

1: $400-500 \mathrm{~mm}$

2. $500-700 \mathrm{~mm}$

non-climate factors

3: $700-900 \mathrm{~mm}$

4: Total

children and elderly persons. The perception of declining income from rainfed crops also corroborates the data. Climate data show that during the past 20 years there has been a recovery rather than a decline in total precipitation (Lebel and Ali 2009), but the decline in August rainfall is crucial for yields as it coincides with grain development.
Finally, the negative perception of production change by farmers is partly corroborated by national statistics on yield and production. Pearl millet production and yields have, for example, remained stable during the past 20 years in four of the five countries despite high population growth; only Nigeria has experienced production and yield 
Fig. 5. Household perceptions of adaptation measures in response to negative trends in rainfed crop production and livestock production, by rainfall zone.
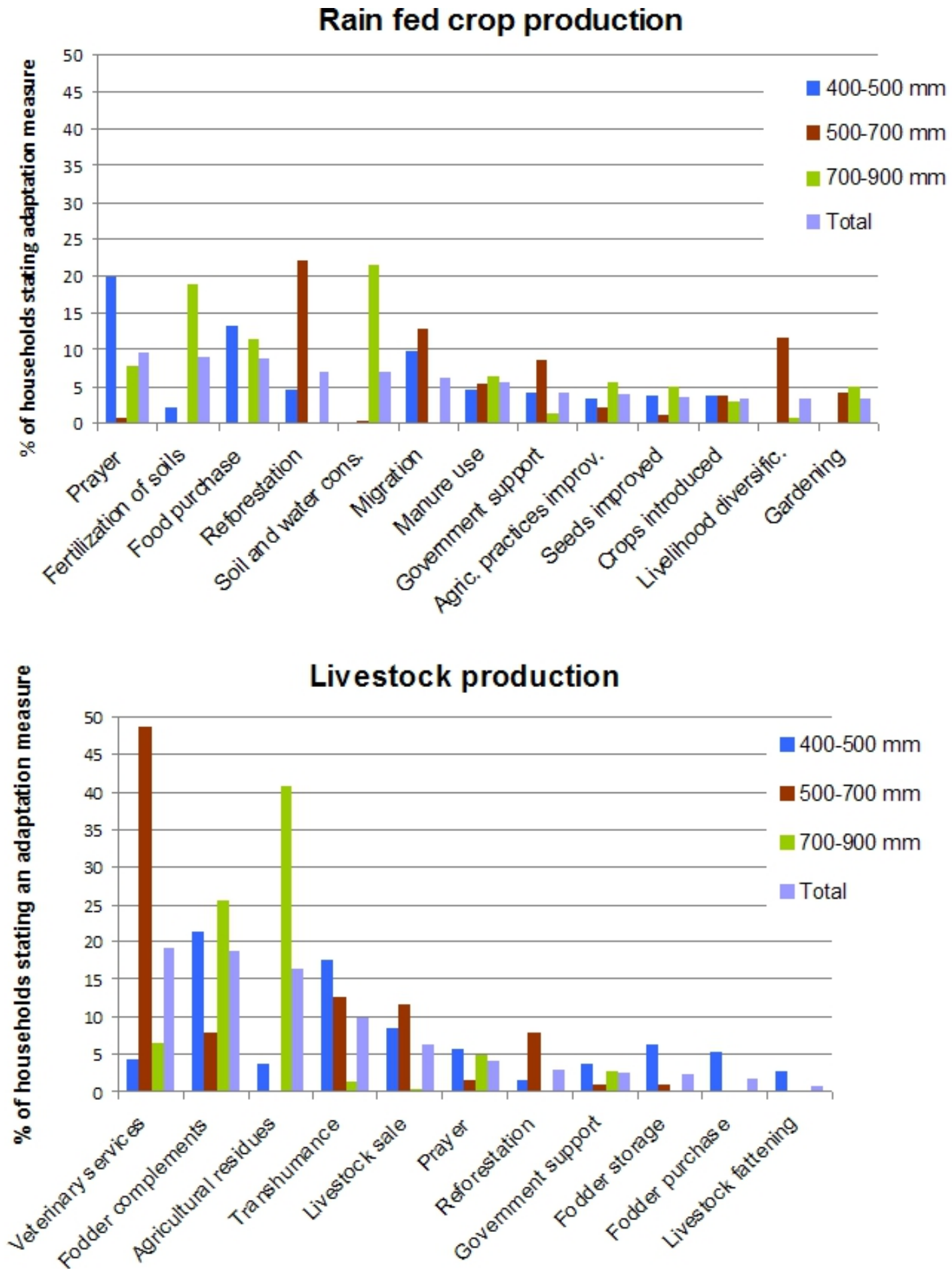
growth (generated from FAOSTAT data from 1988-2008, http://faostat.fao.org/).

It is not surprising that the relative weight of climate factors as perceived determinants of decline in crop production is in the range of $30-50 \%$. Interannual rainfall variability in the Sahel is very high and increasing (Ali and Lebel 2009), and higher wind speeds during rain events may also affect crops negatively (Mertz et al. 2009b). Moreover, rainfall in the Sahel fluctuates across the region and over time "leaving some areas in some years well supplied, yet other regions and other years dry and parched" (Hulme 2001:19). What characterizes the region is thus a high degree of spatial and temporal variability in precipitation. The large number of other factors affecting crop production, however, shows that focusing adaptation options narrowly on climate variability and change will not be sufficient. Household perceptions of current and future adaptation needs point to important measures that are not directly climate related. First of all, it is interesting that the most cited adaptation measure is prayer. This suggests that almost $10 \%$ of households, and $20 \%$ in the driest zone, appear to be unable to see any technical solution to their difficulties related to rainfed crop production. However, they are 'still in business' as farmers (Mortimore and Adams 2001) and the answer 'prayer' may also reflect a lack of understanding of the more subtle connections between lack of rain and technical solutions to adapt to this problem; people feel, rightly, that they can do nothing about the weather. The importance of soil improvement is emphasized by the group of adaptation measures composed of 'soil fertilization', 'soil and water conservation', 'manure use', 'fertilizer use', and 'mulching'. Unfortunately, we do not have data on changes in soil fertility, but it is likely that limited use of fallowing and fertilizers has caused a decline in soil fertility in many areas (Tilander and Bonzi 1997, Reij et al. 2005). Also, the proposed adaptation measures suggest a strong interest in agricultural intensification, which can indeed improve soil fertility (Rovere et al. 2008). Intensification includes crop-livestock interaction and mechanization, as observed in many other studies (Adams and Mortimore 1997, Piraux et al. 1997, Mortimore and Turner 2005), and are not closely linked to climate; soil fertilization is of course beneficial if the rain falls as expected, but can also be a costly investment if the rains fail. The reforestation suggested by households in the intermediate zone may be linked to the high population density and higher degree of deforestation in this zone. The strong focus by many projects and extension workers on tree planting in this zone and a rather strong 'reforestation discourse' (Reenberg et al. 2003, Ozer 2004) probably have influenced farmers' views on how reforestation can benefit agriculture.

The general perception of decreasing livestock numbers may be affected by the fact that counting livestock is a very sensitive issue in the region and farmers may see an advantage in claiming a decline rather than an increase in case the data should serve as basis for a project or taxation. However, the data corroborate the trend of livestock increasingly being owned by fewer larger investors (Turner 2009) rather than the smallholders interviewed in this study.

The perceived increase in land used for pasture, livestock corridors, and resting areas in the dry zone corresponds well with the recovery observed in the natural vegetation in the northern parts of Sahel during the past decades (Olsson et al. 2005, Bolwig et al. 2011). However, farmers mainly attributed this to the government-driven development of pastoral areas as well as land tenure policies, which have provided better protection of pasture from agricultural expansion. Abandonment of fields due to lack of labor, seed supply, and farm equipment was also mentioned by households in Senegal as a cause of increased pasture areas. The decrease in the $700-900 \mathrm{~mm}$ rainfall zone is corroborated by studies showing agricultural expansion onto bush land (Reenberg et al. 2003), which leads not only to limitations on pastoral movements but also to a diminishing potential for fertilization based on croplivestock interaction. The mainly nonclimatic causes of the decline in animal numbers suggests a rather climate robust livestock sector, particularly in the driest zone, where mobility is an important element in adapting to a variable climate. However, plenty of other problems such as veterinary services, livestock theft, and availability of fodder, which may or may not be climate related, appear to be more important to address. The most important constraint on natural fodder availability from pasture and on the movement of cattle is without doubt agricultural expansion.

The differences in perceptions between the rainfed crop and livestock sectors and between the different rainfall zones of the Sudano-Sahelian region leads to a complex dilemma for adaptation, especially in 
the wettest zones studied. Rainfed crop production, which is constrained by climate factors, is apparently expanding at the expense of livestock numbers, which in turn are much less sensitive to climate factors. In the driest zone, the picture is clearer as livestock seems to be the only sustainable solution if agriculture is to persist in the future. Moreover, the importance of income sources seems to be shifting toward nonfarm or small-scale dry season vegetable horticulture, indicating that people are slowly moving out of agriculture.

These differences and dilemmas present important challenges for the development of national adaptation strategies such as National Adaptation Programs of Action (NAPA) as well as efforts to mainstream adaptation to climate change and variability in general development strategies (Halsnæs and Trærup 2009). Such national approaches will naturally focus on more aggregate levels and it is not always possible to directly link local and national strategies because some of the latter may only be felt indirectly in local areas. However, the local perceptions presented in this study can serve to guide the national strategies and especially test their potential success of outreach. For example, it is obvious that in the sites included in this study, the information obtained from national and regional efforts on seasonal weather forecasting and early warning systems has not been embedded in local perceptions as being important elements for decision making. Moreover, local farmers' increasing inclination toward nonfarm activities as an adaptation to unstable agricultural production needs to be reflected in development strategies.

\section{CONCLUSION}

Although a number of recent papers have questioned whether the importance of climate factors relative to other driving forces is really as significant as 'conventional wisdom' would say (Mortimore and Adams 2001, Tschakert 2007, Mertz et al. 2009b), the results of this paper show that climate factors, mainly inadequate rainfall distribution, are mentioned by $30 \%$ (wettest zone) to $50 \%$ (intermediate zone) of households as a cause of the decline in rainfed crop production. A wide range of other factors make up the remaining $50-70 \%$, each represented with a much lower frequency of replies. In the livestock sector, climate factors are much less important and only $20 \%$ of households attribute the perceived decline in livestock numbers to be caused by inadequate rainfall.

The differences between the rainfed crop and livestock sectors as well as those between the driest and wettest zones studied illustrate the difficulty faced by people on the agricultural margins in the driest part of the Sahel to successfully develop their rainfed agriculture. Whether this is because many areas are simply unsuitable for agriculture or it reflects the inability of agricultural development schemes to effectively comply with the perceived needs of farmers in these areas (or both) is not known. Livestock remains much more important and the state-funded protection of pastoral areas seems to have been the major driver of improvement in this sector. In the wettest zone, people seem still to be confident in agriculture as a livelihood strategy as they propose soil fertilization and soil and water conservation as key measures to improve productivity.

The results of this paper call for developing rainfall zone-specific adaptation strategies to climate change and variability in the Sudano-Sahelian region. This is most likely also the case in similar regions in other parts of Africa and the tropics. The livestock sector should receive top priority in the driest areas, but even in the other rainfall zones it is perceived to be a less climate sensitive activity, mainly under pressure from agricultural expansion. It will be more difficult and costly to adapt the rainfed crop production sector, which is already under considerable stress from climate variability in all zones, to future negative impacts of climate change.

Responses to this article can be read online at: http://www.ecologyandsociety.org/voll5/iss4/art25/ responses/

\section{Acknowledgments:}

This research is part of Work Package 3.2 of the African Monsoon Multidisciplinary Analysis (AMMA). Based on a French initiative, AMMA was built by an international scientific group and is currently funded by a large number of agencies, especially from France, UK, U.S., and Africa. It has been the beneficiary of a major financial contribution from the European Community's Sixth 
Framework Research Programme. Detailed information on scientific coordination and funding is available on the AMMA International web site: http://www.amma-international.org. We are grateful for the assistance and hospitality of all communities that took part in the study.

\section{LITERATURE CITED}

Adams, W. M., and M. Mortimore. 1997. Agricultural intensification and flexibility in the Nigerian Sahel. The Geographical Journal 163:150-160.

Adger, N., S. Agrawala, M. M. Q. Mirza, C. Conde, K. O'Brien, J. Pulhin, R. Pulwarty, B. Smit, and T. Takahashi. 2007. Assessment of adaptation practices, options, constraints and capacity. Pages 717-743 in M. L. Parry, O. F. Canziani, J. P. Palutikof, P. J. van der Linden, and C. E. Hanson, editors. Climate Change 2007: Impacts, Adaptation and Vulnerability. Contribution of Working Group II to the Fourth Assessment Report of the Intergovernmental Panel on Climate Change. Cambridge University Press, Cambridge, UK.

Adger, W., S. Dessai, M. Goulden, M. Hulme, I. Lorenzoni, D. Nelson, L. Naess, J. Wolf, and A. Wreford.2009. Are there social limits to adaptation to climate change? Climatic Change 93:335-354.

Adger, W. N., J. Paavola, S. Huq, and M. J. Mace. 2006. Fairness in adaptation to climate change. MIT Press, Cambridge, Massachusetts, USA.

Ali, A., and T. Lebel. 2009. The Sahelian standardized rainfall index revisited. International Journal of Climatology 29:1705-1714.

Barbier, B., H. Yacouba, H. Karambiri, M. Zorome, and B. Some. 2009. Human vulnerability to climate variability in the Sahel: farmers' adaptation strategies in northern Burkina Faso. Environmental Management 43:790-803.

Berkes, F. 1999. Sacred Ecology. Taylor and Francis, New York, New York, USA.

Bolwig, S., K. Rasmussen, and M. K. Hansen. 2011. New perspectives on natural resource management in the Sahel. Department of Geography and Geology, University of Copenhagen, Copenhagen, Denmark, SEREIN Occasional Papers, in press.

Eakin, H. 2005. Institutional change, climate risk, and rural vulnerability: cases from central Mexico. World Development 33:1923-1938.

Halsnæs, K., and S. Trærup. 2009. Development and climate change: a mainstreaming approach for assessing economic, social, and environmental impacts of adaptation measures. Environmental Management 43:765-778.

Hulme, M. 2001. Climatic perspectives on Sahelian desiccation: 1973-1998. Global Environmental Change 11:19-29.

Inglis, J. T. 1993. Traditional ecological knowledge: concepts and cases. International Development Research Center, Ottawa, Ontario, Canada.

Lambin, E. F., B. L. Turner, H. J. Geist, S. B. Agbola, A. Angelsen, J. W. Bruce, O. T. Coomes, R. Dirzo, G. Fischer, C. Folke, P. George, K. Homewood, J. Imbernon, R. Leemans, X. Li, E. F. Moran, M. Mortimore, P. S. Ramakrishnan, J. F. Richards, H. Skånes, W.Steffen, G. D.Stone, U. Svedin, T. A. Veldkamp, C. Vogel, and J. Xu. 2001. The causes of land-use and land-cover change: moving beyond the myths. Global Environmental Change 11:261-269.

Lebel, T., and A. Ali. 2009. Recent trends in the Central and Western Sahel rainfall regime (1990-2007). Journal of Hydrology 375:52-64.

Leichenko, R. M., and K. O'Brien. 2008. Environmental change and globalization. Double exposures. Oxford University Press, Oxford, UK.

Mbow, C., O. Mertz, A. Diouf, K. Rasmussen, and A. Reenberg. 2008. The history of environmental change and adaptation in eastern Saloum-Senegal - Driving forces and perceptions. Global and Planetary Change 64:210-221.

Mertz, O., K. Halsnæes, J. E. Olesen, and K. Rasmussen. 2009a. Adaptation to climate change in developing countries. Environmental Management 43:43-752. 
Mertz, O., C. Mbow, A. Reenberg, and A. Diouf. $2009 b$. Farmers' perceptions of climate change and agricultural adaptation strategies in rural Sahel. Environmental Management 43:804-816.

Mortimore, M., M. Ba, A. Mahamane, R. S. Rostom, P. Serra del Pozo, and B. Turner. 2005. Changing systems and changing landscapes: measuring and interpreting land use transformations in African drylands. Geografisk Tidsskrift, Danish Journal of Geography 105:101-120.

Mortimore, M., and B. Turner. 2005. Does the Sahelian smallholder's management of woodland, farm trees, rangeland support the hypothesis of human-induced desertification? Journal of Arid Environments 63:567-595.

Mortimore, M. J., and W. M. Adams. 2001. Farmer adaptation, change and 'crisis' in the Sahel. Global Environmental Change-Human and Policy Dimensions 11:49-57.

Nicholson, S. 1978. Climatic variation in the Sahel and other African regions during the past five centuries. Journal of Arid Environments 1:3-24.

Nielsen, J. Ø., and A. Reenberg. 2010a. Temporality and the problem with singling out climate as a current driver of change in a small West African village. Journal of Arid Environments 74:464-474.

Nielsen, J. Ø., and A. Reenberg. 2010b. Cultural barriers to climate change adaptation: a case study from Northern Burkina Faso. Global Environmental Change 20:142-152.

Oliver-Smith, A., and S. M. Hoffman. 2002. Introduction. Why Anthropologists should study disasters. Pages 3-22 in S. M. Hoffman and A. Oliver-Smith, editors. Catastrophe and culture. The anthropology of disaster. School of Advanced Research Press, Santa Fe, New Mexico, USA.

Olsson, L., L. Eklundh, and J. Ardö. 2005. A recent greening of the Sahel - trends, patterns and potential causes. Journal of Arid Environments 63:556-566.

Ozer, P. 2004. Bois de feu et déboisement au Sahel: mise au point. [Firewood and deforestation in the Sahel.] Sécheresse 15:241-251.
Parry, M., N. Arnell, P. Berry, D. Dodman, S. Fankhauser, C. Hope, S. Kovats, R. Nicholl, D. Sattherwaite, R. Tiffin, and T. Wheeler. 2009. Assessing the costs of adaptation to climate change: a critique of the UNFCCC estimates. International Institute for Environment and Development, London, UK.

Patt, A. G., M. Tadross, P. Nussbaumer, K. Asante, M. Metzger, J. Rafael, A. Goujon, and G. Brundrit. 2010. Estimating least-developed countries' vulnerability to climate-related extreme events over the next 50 years. Proceedings of the National Academy of Sciences 107:1333-1337.

Piraux, M.,A. Buldger, P. Steyaert, and A. Dieng. 1997. Intensification agricole en région sahélosoudanienne. 2. Productivité et rusques économiques. [Agricultural intensification in the Sudano-Sahelian region. 2. Productivity and economic risks.] Biotechnology, Agronomy, Society and Environment 1(3):209-220.

Rain, D. 1999. Eaters of the dry season. Circular labor migration in the West African Sahel. Westview Press, Boulder, Colorado, USA.

Reenberg, A. 2001. Agricultural land use pattern dynamics in the Sudan-Sahel-towards an eventdriven framework. Land Use Policy 18:309-319.

Reenberg, A. 2009. Embedded flexibility in coupled human-environmental systems in the Sahel: talking about resilience. Pages 132-158 in K. Hastrup, editor. The question of resilience. Social responses to climate changes. The Royal Danish Academy of Sciences and Letters, Copenhagen, Denmark.

Reenberg, A., P. Oksen, and J. Svendsen. 2003. Land use changes vis-à-vis agricultural potential in southeastern Burkina Faso: the field expansion paradox. Geografisk Tidsskrift, Danish Journal of Geography 103:57-64.

Reid, P., and C. Vogel. 2006. Living and responding to multiple stressors in South Africa--Glimpses from KwaZulu-Natal. Global Environmental Change 16:195-206.

Reij, C., G. Tappan, and A. Belemvire. 2005. Changing land management practices and vegetation on the Central Plateau of Burkina Faso 
(1968-2002). Journal of Arid Environments 63:642-659.

Reynolds, J. F., D. M. S. Smith, E. F. Lambin, B. L. Turner, II, M. Mortimore, S. P. J. Batterbury, T. E. Downing, H. Dowlatabadi, R. J. Fernandez, J. E. Herrick, E. Huber-Sannwald, H. Jiang, R. Leemans, T. Lynam, F. T. Maestre, M. Ayarza, and B. Walker. 2007. Global desertification: building a science for dryland development. Science 316:847-851.

Roncoli, C., K. Ingram, and P. Kirshen. 2001. The costs and risks of coping with drought: livelihood impacts and farmers' responses in Burkina Faso. Climate Research 19:119-132.

Rovere, R. L., H. Keulen van, P. Hiernaux, J. Szonyi, and A. Schipper. 2008. Intensification scenarios in south-western Niger: implications for revisiting fertilizer policy. Food Policy 33:156-164.

Slegers, M. F. W. 2008. "If only it would rain": Farmers' perceptions of rainfall and drought in semiarid central Tanzania. Journal of Arid Environments 72:2106-2123.

Thomas, D., C. Twyman, H. Osbahr, and B. Hewitson. 2007. Adaptation to climate change and variability: farmer responses to intra-seasonal precipitation trends in South Africa. Climatic Change 83:301-322.

Tilander, Y., and M. Bonzi. 1997. Water and nutrient conservation through the use of agroforestry mulches, and sorghum yield response. Plant and Soil 197:219-232.

Tschakert, P. 2007. Views from the vulnerable: understanding climatic and other stressors in the Sahel. Global Environmental Change 17:381-396.

Turner, B. L., R. E. Kasperson, P. A. Matson, J. J. McCarthy, R. W. Corell, L. Christensen, N. Eckley, J. X. Kasperson, A. Luers, M. L. Martello, C. Polsky, A. Pulsipher, and A. Schiller. 2003. A framework for vulnerability analysis in sustainability science. Proceedings of the National Academy of Sciences of the United States of America 100:8074-8079.

Turner, B. L., E. F. Lambin, and A. Reenberg. 2007. The emergence of land change science for global environmental change and sustainability.
Proceedings of the National Academy of Sciences of the United States of America 104:20666-20671.

Turner, M. D. 2009. Capital on the move: the changing relation between livestock and labor in Mali, West Africa. Geoforum 40:746-755.

Vedwan, N. 2006. Culture, climate and the environment: local knowledge and perception of climate change among apple growers in northwestern India. Journal of Ecological Anthropology 10:4-15.

West, C. T., C. Roncoli, and F. Ouattara. 2008. Local perceptions and regional climate trends on the central plateau of Burkina Faso. Land Degradation \& Development 19:289-304.

Ziervogel, G., S. Bharwani, and T. E. Downing. 2006. Adapting to climate variability: pumpkins, people and policy. Natural Resources Forum 30:294-305. 